\title{
Simulation of Effects of Using Capacitor for Reactive Power (VAR) Compensation on Electrical Power Supply Quality
}

\author{
Siti Saodah ${ }^{1}$, I Made Wiwit Kastawan ${ }^{2, *}$, Erwin Yusuf ${ }^{1}$, \\ Bambang Puguh Manunggal ${ }^{2}$, Maryanti Maryanti ${ }^{2}$
}

\author{
${ }^{1}$ Diplome-IV Program Study of Electrical Power Plant Technology, Department of Energy Conversion Engineering, \\ Politeknik Negeri Bandung \\ ${ }^{2}$ Diplome-III Program Study of Energy Conversion Engineering, Department of Energy Conversion Engineering, \\ Politeknik Negeri Bandung \\ *Corresponding author. Email: wiwit.kastawan@polban.ac.id
}

\begin{abstract}
Electrical load in industrial sector is mainly inductive that requires large amount of reactive power supply. Large reactive power consumption may give problems to electrical power supply and distribution system such as lower power factor, higher power loss for both electrical power distribution system and all electrical power devices connected in it, and higher voltage drop in electrical power distribution system. Therefore, a measure known as reactive power compensation (VAR compensation) by connecting power capacitor as reactive power source need to be taken. However, VAR compensation measure may give other problems to the electrical power supply and distribution system. This paper describes effects of using capacitor for VAR compensation to the quality of electrical power supply and distribution system based on simulation run with Matlab Simulink software. Three different kinds of VAR compensation method are analysed i.e., connecting a small capacitor for each inductive load, connecting a large capacitor at the electrical power supply side in which its reactive power flow is controlled by SVC (static VAR compensator) method and connecting a large capacitor at the electrical power supply side in which its reactive power flow is controlled by TSC (thyristor switched capacitor) method. Analysis results show that all the three VAR compensation methods successfully improve or increase power factor of the electrical power supply and distribution system close to unity. However, both the SVC and TSC VAR compensation methods increase harmonic content of voltage and current of the electrical power supply and distribution system as indicated by its high total harmonic distortion (THD) value. On contrary, the VAR compensation method by connecting a small capacitor for each inductive load brings no effect on increasing of harmonic content of voltage and current of the electrical power supply and distribution system.
\end{abstract}

Keywords: compensation, harmonics, power factor, reactive power, SVC, TSC.

\section{INTRODUCTION}

In industry, inductive electrical loads are widely used. One of them is an induction motor. The installation of electric motors can use up to $70 \%$ of the total power in the industry [1]. An induction motor consists of two main parts, namely the stator coil $\left(\mathrm{N}_{1}\right)$ and the rotor coil $\left(\mathrm{N}_{2}\right)$. The equivalent circuit of an induction motor can be described as follows (Figure 1).

The use of this inductive load causes an increase in reactive power. As a result of this increased reactive power, the power factor in the network becomes lower. In addition, the increase in reactive power can cause the current to be higher so that copper losses increase, and the voltage drop increases which can cause lower efficiency.

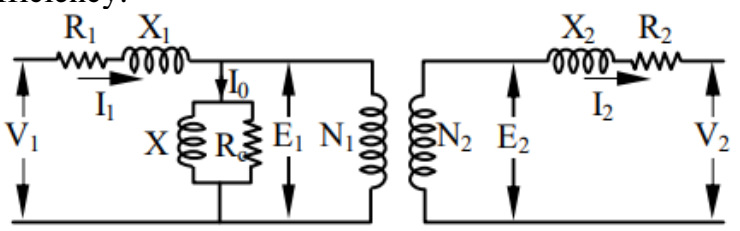

Figure 1 Motor equivalent circuit 
Therefore, improvements are made in the industry to get a better power factor. Power factor improvement can be done in several ways, including the installation of capacitors or synchronous motors. The use of synchronous motors for reactive power compensation is by adjusting the excitation current in the rotor coil until the desired power factor is obtained.

Capacitors used for power factor improvement do to supply reactive power, so that reactive power from the source can be reduced [3]. Installation can be done in series or parallel. The use of series capacitors for reactive power compensation will result in a low voltage drop. So, this series capacitor can be used to reduce the voltage drop in a network that has a low power factor. However, under short circuit conditions, the resulting high voltage can damage the capacitor [4]. Meanwhile, the installation of capacitors in parallel can use permanent capacitors or variable capacitors that can be controlled either manually or automatically. When the reactive power that must be supplied to the network is lower than the reactive power in the capacitor, the reactive power supplied by the capacitor can be controlled by installing several capacitors that can be set on or off in parallel [4].

Three-phase capacitors can be connected in a delta connection or a star connection. In the delta connection, the capacitor is installed in the phase-to-phase line. Thus, the current in the capacitor is equal to the phase current. Also, the voltage across the capacitor is equal to the phase-to-phase voltage. Figure 2 delta connected capacitor circuit is as follows.

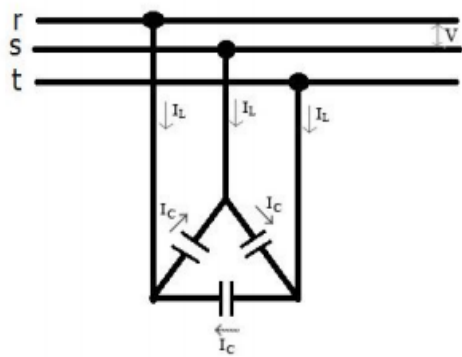

Figure 2 Delta connected capacitor circuit

In the star connection, the capacitor is installed in the phase-neutral line. Thus, the current in the capacitor is equal to the phase-neutral current. Also, the voltage across the capacitor is equal to the phase-neutral voltage. Figure 3 star connected capacitor circuit is as follows.

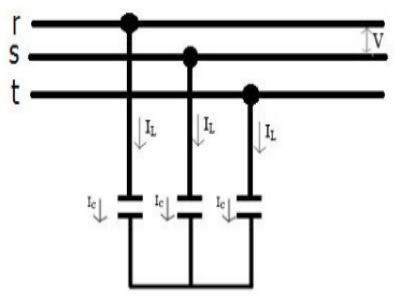

Figure 3 Star connected capacitor circuit
To calculate the capacitance of a capacitor can be done using the following equation:

$Q c=I c \times V c$

The amount of Ic can be determined by using the equation:

$I_{c}=\frac{V_{c}}{X_{c}}$

where,

$X c=\frac{1}{2 \cdot \pi \cdot f \cdot C}$

When equations (3) and (2) are subtracted into equation (1), the following equation is obtained:

$C=\frac{Q c}{2 \cdot \pi \cdot f \cdot V_{c}^{2}}$

The value of $V_{c}$ and $I_{c}$ depends on the three-phase circuit used [5].

The reactive power compensation carried out allows for other effects apart from improving the power factor. In some scientific works that are used as a reference source for this research, such as scientific works made by $[5,6,7,8,9,10,11,12]$ has been tested to improve the power factor with several different methods. However, this scientific paper does not discuss the effect of improving these resources, especially on the quality of resources. Therefore, in this study a test was conducted to determine the effect of improving the power factor, especially on the quality of the resource.

One of the power quality parameters of an electric power system can be expressed in THD (Total Harmonic Distortion). This THD states the percentage ratio between a wave and its pure wave, namely a sinusoidal wave if the voltage is AC. This THD parameter is found in both current and voltage waves. These harmonics are caused by distortion of current and voltage waves. This distortion of current and voltage waves causes the voltage and current waveforms to deviate from their proper shape, which is sinusoidal. Harmonics can cause several problems in electric power systems. Some of them can cause heat, wrong readings in measuring electrical quantities, increasing transformer losses, and so on. Figure 4 is a picture of a harmonic wave [10].

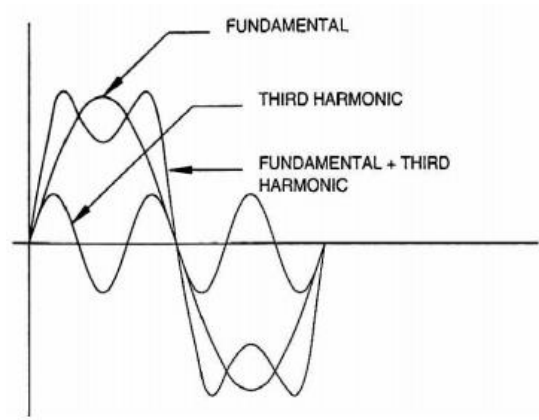

Figure 4 Distorted wave 
The test in this study was carried out on improving the power factor by compensating reactive power using a capacitor, because it is more commonly used. With different methods it is possible to have different effects, so in this study, several different methods will be tested, to find out the comparison of each method. The methods used include installation of capacitors on each load, SVC and TSC.

A thyristor-switched capacitor (TSC) is a type of equipment used to compensate for reactive power in electric power systems. It consists of a power capacitor connected in series with a bidirectional thyristor and, as usually, a current limiting reactor (inductor) [10].

Thyristor Controlled Reactor (TCR) is a device that functions as a reactive power absorber of the system when the system is overloaded with reactive power. Of course, the main component of the TCR is an inductor that is mounted in series with a pair of thyristors. A pair of thyristors are used because they are used to control the positive and negative phases of the system. The TCR consists of an anti-parallel inductor, resistor and thyristor that can be operated by adjusting the ignition angle [10].

Static VAR Compensator (SVC) serves to inject controlled reactive power to control certain variables in an electric power system. In this study, SVC is used to maintain the power factor value. When performing reactive power compensation, no part of the SVC moves, hence the name Static VAR Compensator. The compensation process in this SVC is fully controlled by the power electronics system [13].

Static VAR Compensator (SVC) is a power electronics component consisting of capacitors, reactors, and thyristors that function as switches. Thyristor which works as a switch can be adjusted its output voltage by controlling the ignition angle. The thyristor which functions as a switch on the SVC only flows current in one direction, so two thyristors are used as shown in Figure 5 [13].

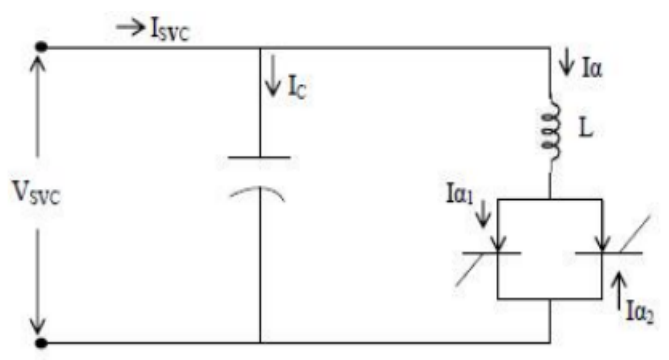

Figure 5 Static VAR compensator (SVC)

SVC and TSC will be controlled by Fuzzy Logic Controller (FLC). Fuzzy logic is known as an effective method for solving complex problems to be solved mathematically using the concept of ambiguity. The advantage of using fuzzy logic is that it does not require a complicated mathematical model, making it easier for the control system design process [10].

\section{METHODOLOGY}

In general, the VAR compensation method has been carried out through the stages described in the flow chart below (Figure 6).

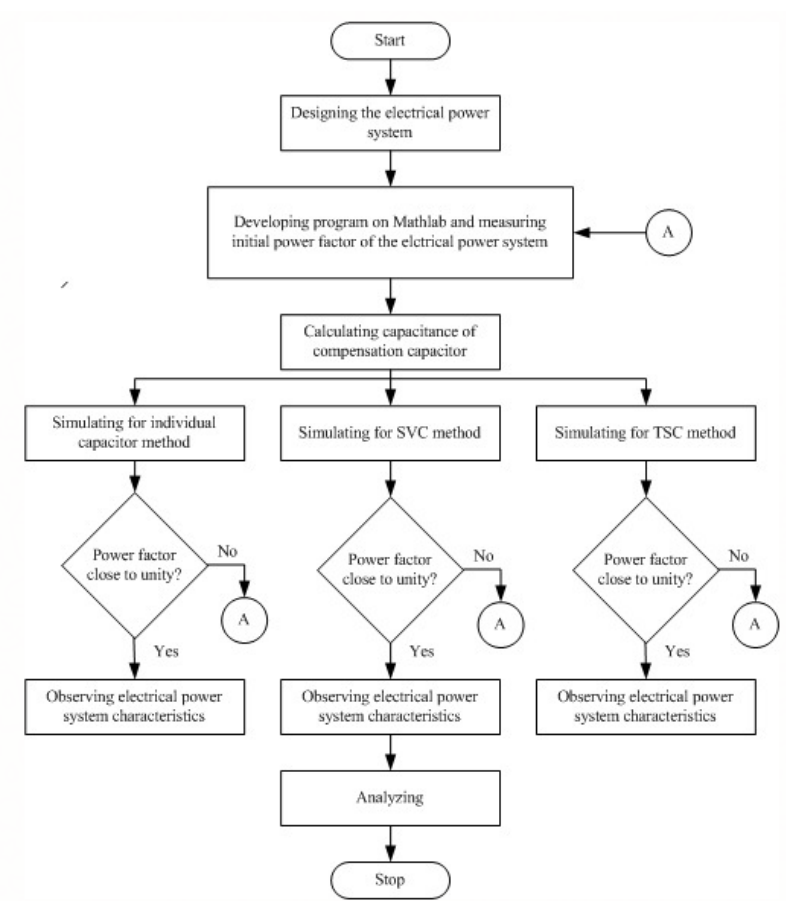

Figure 6 Research flow chart

a) Simulation of initial conditions. This step is intended to determine the power factor value before VAR compensation is carried out.

b) Determination of capacitor value for VAR compensation. Based on the power factor value in the initial conditions, it can be calculated the value of the compensation capacitor needed to increase the power factor value close to 1.0. Two capacitor values were calculated, namely for the capacitor to be installed in each load (motor) and the capacitor to be installed on the source side of the electrical system.

c) Simulation of VAR compensation with the installation of a fixed capacitor in each load.

d) Simulation of VAR compensation with installation of SVC on the source side.

e) Simulation of VAR compensation with TSC installation on the source side.

\section{RESULTS AND DISCUSSION}

The electrical system that is simulated is a threephase ac voltage source of $380 \mathrm{~V}$ (phase-phase), $50 \mathrm{~Hz}$ which supplies a load of 3 three-phase induction motors 
without a drive (soft-starter or VSD). The parameters of these three induction motors are shown in Table 1 below.

Table 1 Load parameters [2, 14]

\begin{tabular}{|c|c|c|c|c|c|c|c|c|}
\hline Load & $\mathrm{V}$ (volt) & $\begin{array}{c}\mathrm{I} \\
(\mathrm{m} p \text { pere) }\end{array}$ & $\begin{array}{c}\mathrm{R}_{\mathrm{r}} \\
(\mathrm{ohm})\end{array}$ & $\begin{array}{c}\mathrm{R}_{\mathrm{s}} \\
(\mathrm{ohm})\end{array}$ & $\begin{array}{c}\mathrm{X}_{\mathrm{H}} \\
(\mathrm{H})\end{array}$ & $\mathrm{X}_{\mathrm{S}}(\mathrm{H})$ & $\mathrm{X}_{\mathrm{m}}(\mathrm{H})$ & $\mathrm{N}(\mathrm{rpm})$ \\
\hline $\begin{array}{c}\text { Motor } \\
1\end{array}$ & 380 & 0.62 & 59.33 & 37.08 & 27.32 & 27.32 & 411.47 & 1380 \\
\hline $\begin{array}{c}\text { Motor } \\
2\end{array}$ & 380 & 2.10 & 11.60 & 9.96 & 15.94 & 15.94 & 174.83 & 1310 \\
\hline $\begin{array}{c}\text { Motor } \\
3\end{array}$ & 380 & 3.80 & 2.34 & 0.85 & 0.03 & 0.03 & 0.87 & 1450 \\
\hline
\end{tabular}

with

Rr : Rotor resistance

Rs : Stator resistance

Xls : Stator leakage inductance

Xlr : Rotor leakage inductance

$\mathrm{Xm}$ : Magnetizing Inductance

$\mathrm{N}$ : Motor rotation speed

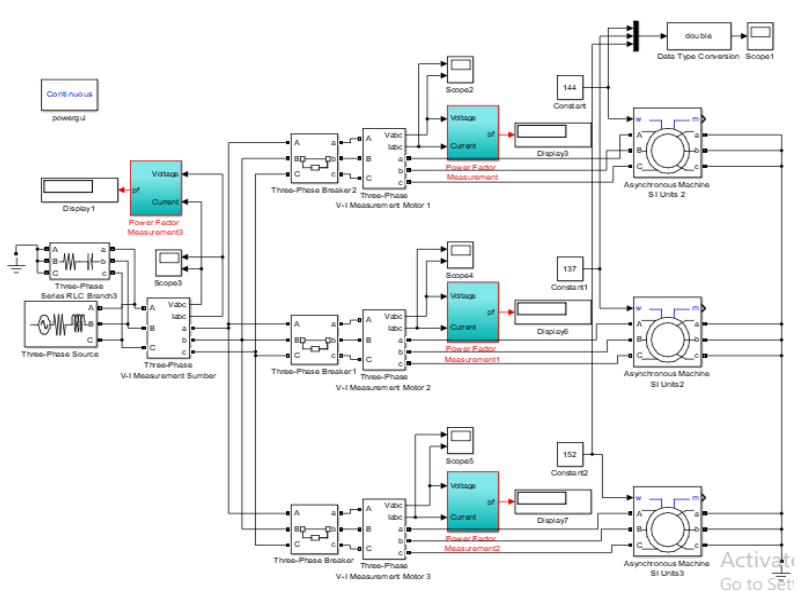

Figure 7 The initial circuit

Furthermore, after reactive power compensation is carried out, power factor and THD measurements are carried out in three conditions, namely when three loads are on, two loads are on (motor 1 and 2 are on, motor 3 is off), and one load is on (motor 1 is on, motor 2 and 3 are off) (Figure 7)

The results of the measurements in the initial circuit are as follows (Table 2, Figure 8 and 9).

Table 2 Measurement results of the initial circuit

\begin{tabular}{|c|c|c|c|c|c|}
\hline \multicolumn{4}{|c|}{ Power factor (pf) } & \multirow{2}{*}{$\begin{array}{c}\mathrm{THD}_{\mathrm{i}} \\
(\%)\end{array}$} & \multirow{2}{*}{$\begin{array}{c}\mathrm{THD}_{\mathrm{V}} \\
(\%)\end{array}$} \\
\hline System & Motor 1 & Motor 2 & Motor 3 & & \\
\hline 0.652 & 0.602 & 0.771 & 0.741 & 0.050 & 0.070 \\
\hline
\end{tabular}

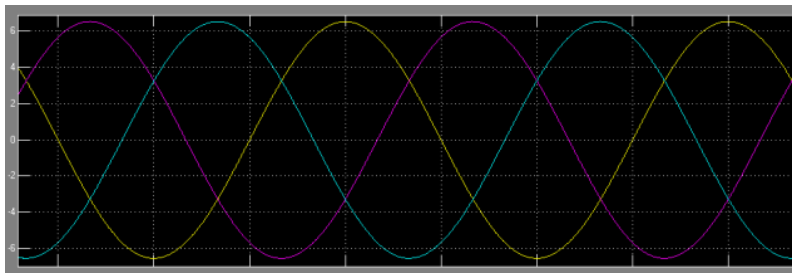

Figure 8 The source current wave in the initial circuit

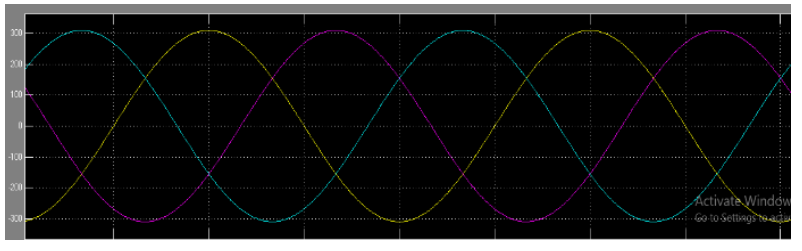

Figure 9 The source voltage waveform in the initial circuit

From the measurement data, the power factor values obtained are different for each load. This initial power factor value becomes a comparison to determine the performance of reactive power compensation carried out.

The voltage and current waveforms of this initial circuit are close to a pure sinusoidal form. This can be seen from the current THD of $0.050 \%$ and the voltage THD of $0.070 \%$

\subsection{Determination of Capacitor Capacitance}

After knowing the value of the initial power factor in the system, then a calculation is carried out to determine the size of the capacitor needed to increase the power factor to close to 1.0. The results of the calculations carried out are as follows (Table 3).

Table 3 Calculation of capacitor capacitance

\begin{tabular}{|c|c|c|c|c|c|c|c|}
\hline Load & $\mathrm{V}$ (volt) & $\begin{array}{c}\text { I } \\
\text { (ampere) }\end{array}$ & $\mathrm{s}(\mathrm{VA})$ & $P(W)$ & $\mathrm{p} \mathrm{f}_{\text {fintitat }}$ & $\begin{array}{c}\begin{array}{c}\mathrm{Q}_{\mathrm{c}} \\
\text { (VAR) }\end{array} \\
\end{array}$ & $\mathrm{C}_{\text {pertphase }}(\mathrm{F})$ \\
\hline Source & 219.38 & 4.61 & 1011.34 & 749.61 & 0.741 & 261.74 & $1.732 \times 10^{-5}$ \\
\hline $\begin{array}{c}\text { Motor } \\
1\end{array}$ & 219.38 & 1.48 & 324.68 & 197.89 & 0.609 & 126.79 & $8.390 \times 10^{-6}$ \\
\hline $\begin{array}{c}\text { Motor } \\
2\end{array}$ & 219.38 & 0.44 & 96.53 & 71.69 & 0.743 & 24.84 & $1.643 \times 10^{-6}$ \\
\hline $\begin{array}{c}\text { Motor } \\
3\end{array}$ & 219.38 & 2.69 & 590.13 & 438.59 & 0.743 & 151.55 & $1.003 \times 10^{-5}$ \\
\hline
\end{tabular}

\subsection{Reactive Power Compensation}

The first reactive power compensation method is the installation of three-phase capacitors on each load in parallel. The circuit diagram after the capacitor is installed is as follows (Figure 10).

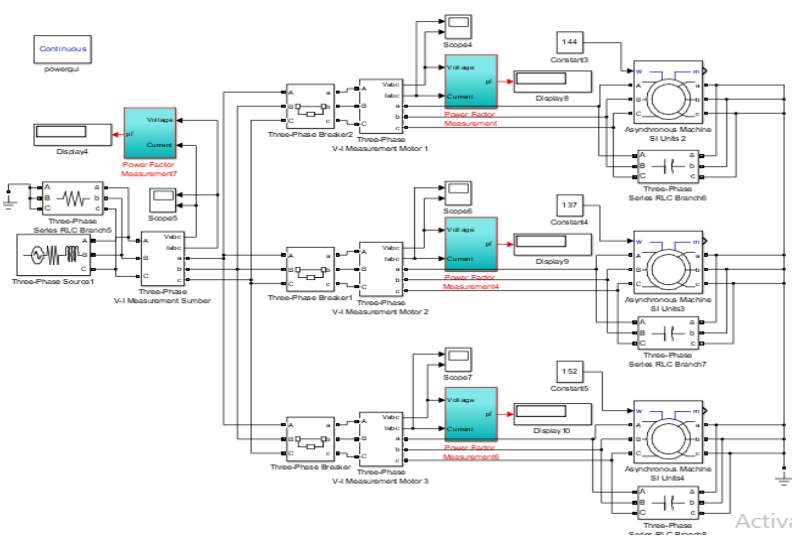

Figure 10 Circuit after capacitor installation

The measurement results of the circuit (Figure 9) are as follows (Table 4, Figure 11 and 12). 
Table 4 Measurement result after capacitor installation at the load side

\begin{tabular}{|c|c|c|c|c|c|c|}
\hline \multirow{2}{*}{ Condition } & \multirow{2}{*}{\multicolumn{4}{|c|}{ Power factor $(\mathrm{pf})$}} & \multirow{2}{*}{$\mathrm{THD}_{\mathrm{i}}(\%)$} & \multirow{2}{*}{ THDy $(\%)$} \\
\hline & & & Motor 2 & Motor 3 & & \\
\hline $\begin{array}{l}\text { Motor } 1,2 \\
\text { and } 3 \text { on }\end{array}$ & 0.9826 & 0.9664 & 0.9729 & 0.9839 & 0 & 0.09 \\
\hline $\begin{array}{l}\text { Motor } 1 \text { and } \\
2 \text { on, Motor } \\
3 \text { off }\end{array}$ & 0.9762 & 0.9660 & 0.9707 & 0.0004 & 0 & 0.07 \\
\hline $\begin{array}{l}\text { Motor } 1 \text { on, } \\
\text { Motor } 2 \text { and } \\
3 \text { on }\end{array}$ & 0.9764 & 0.9664 & 0.0006 & 0.0004 & 0 & 0.07 \\
\hline
\end{tabular}

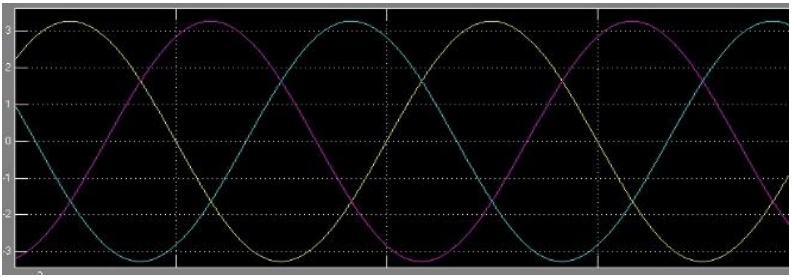

Figure 11 Current wave after capacitor installation

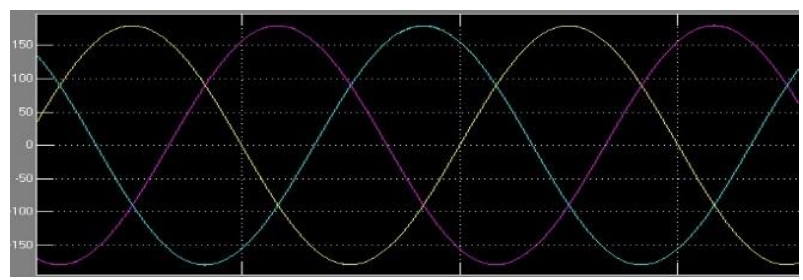

Figure 12 Voltage wave after capacitor installation

The installation of this capacitor does not greatly affect the waveform of the source voltage and current. The decrease in the THD value due to the installation of a capacitor is very small, so it is concluded that the installation of this capacitor does not affect the THD of the system current and voltage.

The advantages of this method are that it does not damage the waveform on the source side, can compensate for reactive power well, and its installation is not complicated because it does not have to use controls for operation. While the drawback is that more capacitors are needed, the more load to be compensated for, the more capacitors needed.

The second reactive power compensation method is the installation of SVC (Static Var Compensator). The circuit diagram after the SCV installation is as follows (Figure 13).

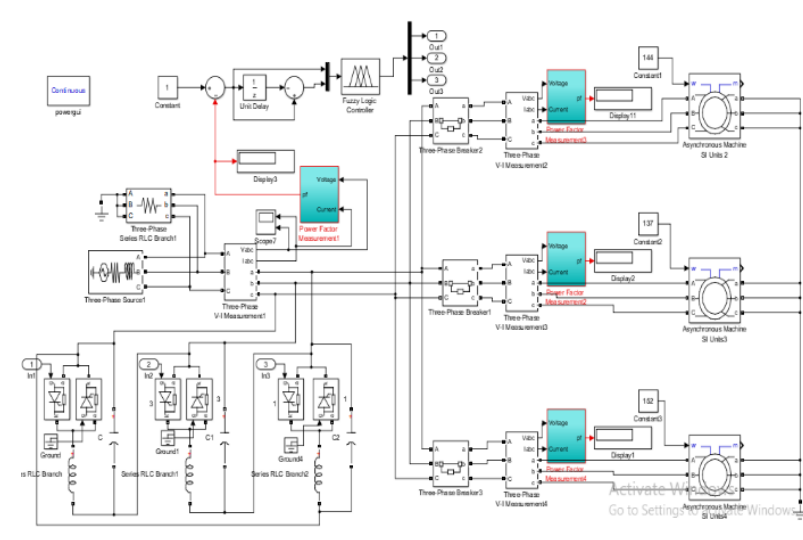

Figure 13 Circuit after SVC installation

The measurement results of the circuit (Figure 12) are as follows (Table 5, Figure 14 and 15).

Table 5 Measurement result after SVC installation

\begin{tabular}{|l|c|c|c|c|c|c|}
\hline \multicolumn{1}{|c|}{ Condition } & Source & Motor 1 & Motor 2 & Motor 3 & THD $(\%)$ & THDv (\%) \\
\hline $\begin{array}{l}\text { Motor 1,2 } \\
\text { and 3 on }\end{array}$ & 0.9613 & 0.6005 & 0.7747 & 0.7324 & 31.08 & 25.82 \\
\hline $\begin{array}{l}\text { Motor 1 and } \\
\text { 2 on, Motor }\end{array}$ & 0.9614 & 0.6045 & 0.7785 & 0 & 30.74 & 24.94 \\
\hline \begin{tabular}{l} 
3off \\
\hline $\begin{array}{l}\text { Motor 1 on, } \\
\text { Motor 2 and } \\
\text { 3 on }\end{array}$
\end{tabular} & 0.9813 & 0.6018 & 0 & 0 & 30.36 & 24.77 \\
\hline
\end{tabular}

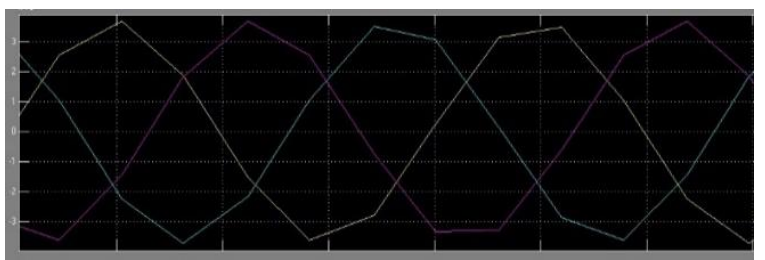

Figure 14 Current wave after installation of SVC

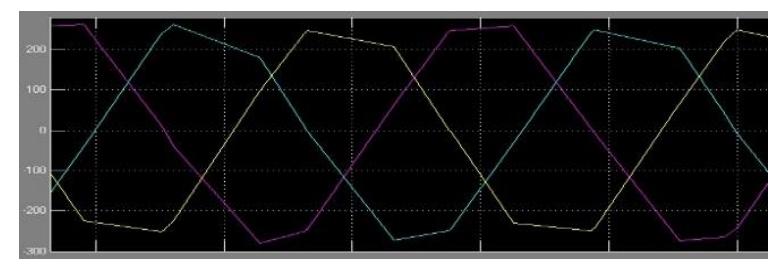

Figure 15 Voltage wave after installation of SVC

After installing this SVC, the power factor is close to 1.0. The current and voltage THD after the SVC installation increased up to $30.74 \%$. From these data, it can be concluded that in this simulation, the installation of SVC damages the source THD.

This increase in the THD value is not good because it can cause losses as discussed on the theoretical basis. The use of SVC for reactive power compensation is good if a filter is added to the circuit to reduce THD.

The third reactive power compensation method is the installation of TSC (Thyristor Switch Capacitor). The circuit diagram after TSC is installed is as follows (Figure 16). 


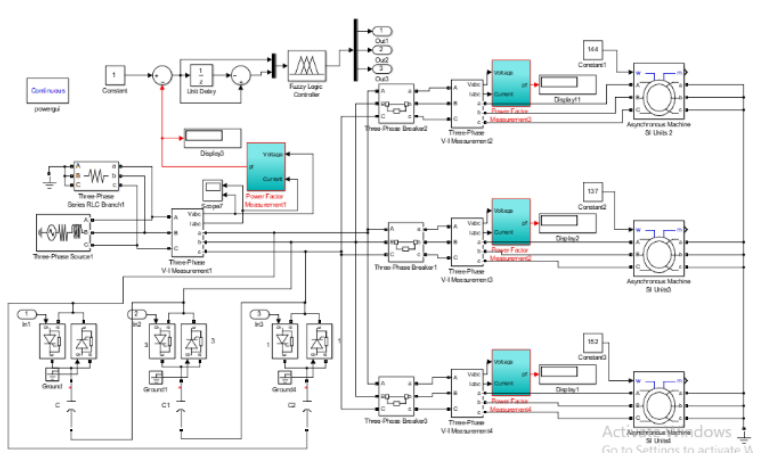

Figure 16 Circuit after TSC installation

The measurement results in the circuit (Figure 16) are as follows (Table 6, Figure 17 and 18).

Table 6 Measurement result after TSC installation

\begin{tabular}{|c|c|c|c|c|c|c|}
\hline \multirow{2}{*}{ Condition } & \multirow{2}{*}{\multicolumn{4}{|c|}{ Power factor (pf) }} & \multirow{2}{*}{$\underline{\mathrm{THD}} \mathbf{i}(\%)$} & \multirow{2}{*}{ THDv (\%) } \\
\hline & Source & & & & & \\
\hline $\begin{array}{l}\text { Motor } 1,2 \\
\text { and } 3 \text { on }\end{array}$ & 0.9867 & 0.6045 & 0.7746 & 0.7404 & 35.46 & 27.15 \\
\hline $\begin{array}{l}\begin{array}{l}\text { Motor } 1 \text { and } \\
2 \text { on, Motor } \\
3 \text { off }\end{array} \\
\end{array}$ & 0.9810 & 0.6047 & 0.7749 & 0 & 34.85 & 26.88 \\
\hline $\begin{array}{l}\text { Motor } 1 \text { on, } \\
\text { Motor } 2 \text { and } \\
3 \text { on }\end{array}$ & 0.9810 & 0.6047 & 0 & 0 & 34.85 & 26.76 \\
\hline
\end{tabular}

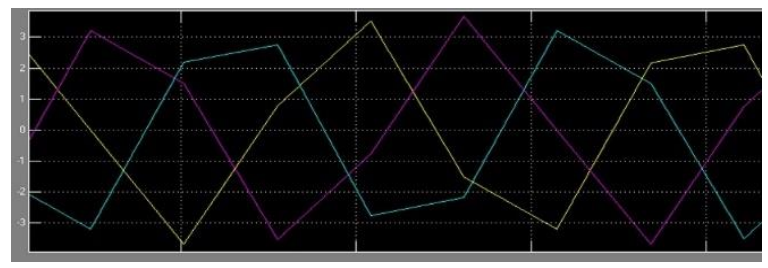

Figure 17 Current wave after installation of TSC

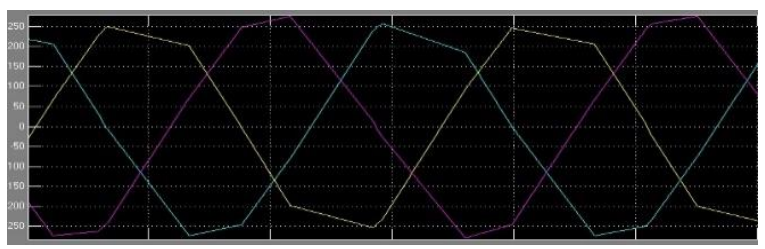

Figure 18 Voltage wave after installation of TSC

After TSC installation, the power factor is close to 1.0. The current THD in the network after the installation of this TSC increased quite high up to $35.46 \%$. As in the reactive power compensation method using SVC, the use of TSC for reactive power compensation is best used if a filter is added to the circuit to reduce THD.

\section{CONCLUSIONS AND SUGGESTIONS}

\subsection{Conclusions}

Reactive power compensation with capacitors can improve power factor and not damage current and voltage waves. While reactive power compensation by installing SVC and TSC can improve the power factor well but damage the current and voltage waves.
If it is seen from the reactive power compensation performance and the effect on THD only, the reactive power compensation method that is better done is by installing ordinary capacitors.

\subsection{Suggestions}

Reactive power compensation in networks with a large number of loads is better done by installing SVC or TSC and adding filters to reduce THD.

\section{ACKNOWLEDGMENTS}

This research was funded and supported by Pusat Penelitian dan Pengabdian Kepada Masyarakat (P3M), Politeknik Negeri Bandung

\section{REFERENCES}

[1] T. P. D. Zainal Abidin, in Bahasa, Performance Test of 3HP AC Three-Phase Induction Motor with Generator Load, Momentum, pp. 30-34, 2013.

[2] W. Alhabshi, T. Yuwono, S. Anam, in Bahasa, Estimating Power Factor of Three-Phase Induction Motor by Measured Cuurent and Specification Data, 2012.

[3] F. A. Noor, H. Ananta, S. Sunardiyo, in Bahasa, The Effect of Adding Capacitor to Voltage, Current, Power Factor and Active Power of a Minimart Electrical Load, 2017, Jurnal Teknik Elektro, vol. 9, no. 2 , pp. 66-73.

[4] I. K. Kiran dan J. L. A, Shunt Versus Series Compensation in The Improvement of Power System Performance, 2011.

[5] A. R. Lubis, in Bahasa, The Effectivity of Using Passive LC Filter, 2017, Journal of Electrical Technology, pp. 1-8.

[6] A. K. A. Bahar, in Bahasa, Analysis of Effect of Capacitor Bank to Power Factor of TI BRI RAGUNAN Building, 2017, Jurnal Ilmiah Elektrokrisna, pp. 9-22.

[7] M. F. Hakim, in Bahasa, Analysis of Capacitor Bank Need and Implementation for Power Factor Correction at POLITEKNIK KOTA MALANG, 2014, Jurnal ELTEK, Vol 12 Nomor 01, pp. 105118.

[8] Hermagasantos Zein, Optimal Location of a Capacitor Bank in a Primary Feeder to Load up Linearly, 2014, IPTEK, Journal of Proceeding Series, Vol. 1, pp. 125-129.

[9] M. N. Sonni, in Bahasa, Comparison Between Centralized Reactive Power Compensation and Distributed Reactive Power Compensation to 
Improvement of Voltage Stabilization of SUMBAR

- RIAU Electrical Power System, 2010, Jurnal TEKNIKA No.33 Vol.1, pp. 48 - 54.

[10] K. Widarsono, in Bahasa, Reactive Power Compensation for Industrial Power System Using Passive Filter and Fuzzy Logic Controller Based Thyristor Controlled Reactor (TCR), 2010.

[11] Y. Yunus, in Bahasa, Power Factor Correction of Three-Phase Induction Motor, 2010.
[12] A. Satria dan E. Ervianto, in Bahasa, Power Factor Correction Using Synchronous Motor with Fuzzy Logic Control Method, 2017.

[13] A. W. Bangun, in Bahasa, Determine of Location of SVC (Static Var Compensator) to Improve Voltage Profile of Transmission Line of PT.PLN Lampung, 2016.

[14] T. Sucita dan L. Alhapip, in Bahasa, No-Load Analysis of Induction Motor, 2002. 